\title{
Chapter 2. The Water That Blesses, The River That Flows: Place And The Ritual Imagination Among The Temanambondro Of Southeast Madagascar $^{1}$
}

\section{Philip Thomas}

\section{The Place-Ness of Water}

Not long after beginning fieldwork in the village of Manambondro in coastal southeast Madagascar, I was called one evening to the house of the "headman" of the house-group in which I was domiciled. Gathered together there in the encroaching gloom of dusk were several men, to whom the purpose of my visit was being explained. When one man heard that it was my hope to learn to speak the dialect of Malagasy spoken thereabouts he interjected to the effect that I would learn the language as quickly and easily as I drank the water of the Manambondro River.

As I did not see a great deal of significance in it at the time it was made, I failed to follow up this intriguing remark, which linked a particular aspect of local ways of doing things (fomba), dialect, to a feature of the landscape, the river. In time, however, I came to realize that the Manambondro River and its water were important elements in what, to paraphrase Fernandez (1982), I have chosen to call the Temanambondro "ritual imagination". The water of the Manambondro is said to possess "sacred efficacy" (hasy), and is used in a variety of rites of blessing and purification. In this regard Temanambondro rituals appear simply to be a variant of more widespread practices in Madagascar, in which water is employed as a vehicle of blessing. However, as I will argue, while water itself may have great ritual significance, just as, if not more, important is the place where that water comes from.

Water figures in a large number of ethnographic accounts of rituals among the peoples of Madagascar. Every ten years or so the Sakalava of Menabe on the west coast bathe the relics of their deceased rulers in the river that runs through the centre of their domain (Nérine Botokeky 1983), a rite similar to those of other Sakalava polities to their north (Feeley-Harnik 1991b:102-103). Across the island in the forests of the eastern escarpment a similar practice is to be found among the Tañala who themselves say that this custom originated in the southwest of the island (Beaujard 1983a:317-319, 1983b:332-337). Here, the relics of former 
rulers are taken each year and submerged in water at the confluence of two rivers into which runs the blood of a sacrificed bull.

These rites, involving the purification of ancestors, are known as "baths" (fandroana), and are similar in many respects to rites of the Tanosy and Temoro of Madagascar's east coast and the Merina of the central highlands, although here it is living rulers who are bathed, rather than the remains of their dead predecessors (see Molet 1956). Although the rite is now rarely practised, among the Temoro the "bath" was an annual event which marked the beginning of the new year, and involved the "ruler" (mpanjaka) bathing in the water at the mouth of a river (Chandon-Moet 1972:52; Rolland 1984:118-120). In Imerina the ritual of the royal bath similarly marked the transition from one year to the next, and involved rulers bathing themselves in water mixed with earth taken from the tomb of their ancestors, water which was later used for the blessing of the rulers' subjects (Bloch 1987). That the bathing of royal relics, like the ritual of the bath, has also to do with blessing and fertility in its widest sense is clear from two accounts of its origin (Nérine Botokeky 1983:212; Beaujard 1983b:332).

We can begin to look more closely at the ritual significance of water in these and other rites by considering Maurice Bloch's analysis of Merina blessing (Bloch 1986). Blessing, Bloch contends, underlies Merina practices of secondary burial, circumcision and the royal bath, and is centrally important to Merina notions of descent and descent-groups, or demes (1986:39-47). In the Merina dialect the term for blessing suggests vividly what it involves, for it translates as "the blowing on of water", and during the act of blessing the male elder who administers it blesses the supplicants with water by blowing and spraying it over them.

There is however a certain ambiguity about the source of the fertility that is diverted in Merina blessing, an ambiguity associated with ideas about land. According to Bloch, "water is associated with the unappropriated fertility of the land" (1986:41), an idea which contrasts with a different notion of the fertility of the deme and its appropriated land, an opposition which is represented in terms of the tomb. Being the containers of the previous generations of the deme, tombs are the source of blessing and fertility. Demes are also eternally associated with particular tracts of land, with tombs being the very evidence of this association. Yet Merina recognize that they themselves are not true autochthons of the lands they occupy, lands which were once occupied by others whom the Merina conquered. And it is these true autochthons, the Vazimba, whom Merina associate with notions of a "wild" fertility found outside the authority of the deme and above all associated with water. Merina blessing then is a canalization of the "wild" power of the true owners of the land, here represented in water, through the words and mouths of the land's current occupiers (1986:41-43). 
Nowhere is this canalization more graphically realized than in the practice of placing water on a tomb prior to its use in blessing.

But whilst Merina blessing involves placing water on tombs, in his account of the royal bath Bloch also makes clear that the water used in the ritual came from a particular place or places, lakes in which Vazimba queens were said to have been buried (Bloch 1987:280). There appears therefore to be something rather particular about the source of the water for blessing, and it is this dimension of water which concerns me here: its association with particular places. For whilst one may analyse the ritual significance of water in terms of its use in blessing, or its association with "rulers" and royalty (Beaujard 1983a), what is especially striking about the use of water in many Malagasy rituals is that it is an important element in making rituals place-specific. Royal baths and the bathing of relics, for example, occur in particular places, or, in the Merina case, use water drawn from particular places. Once one sees water not simply as a vehicle for blessing, but as a substance associated with particular places, it becomes clear that water courses and sources are part of a symbolic geography and ritual topography among many Malagasy peoples. Water thus appears significant not simply in and of itself, but as part of local cartographies of the sacred, and nowhere is this more so than in the east of Madagascar, where rivers, and in particular their confluents and embouchures, figure as focal places for a variety of rites.

Among Betsimisaraka of the northeast, for example, Cotte reports that springs, rapids and waterfalls are "places of cult", and that "spirits" inhabit river confluents (Cotte 1947:62, 161, 172). Similarly, in the southeast of the island male circumcision rituals involve the use of water as a vehicle of blessing and healing, and reports of these reveal that the source of water, often a particular river or spring, is itself of great importance (Rajohnson 1908:178; Deschamps and Vianès 1959:22-23, 60; Chandon-Moet 1972:105-106; Beaujard 1983a:314). Finally, and perhaps most striking, is a rite found widely along the east coast, and which accords as much, if not more, importance to the river as it does to the water it contains. This rite is performed to clear the mouth of a river which has become barred by a sandbank, or when other inauspicious events signal that the river needs purifying (Cotte 1947:150-152; Deschamps and Vianès 1959:21， 79; Chandon-Moet 1972:67-68; Rahatoka 1984:77-79). Among Temanambondro the rite is known as a sao-binañy, "blessing of the river mouth", and is said to "cleanse the river" (mampadio renirano) and thus return "sacred efficacy" (hasy) to the water it contains.

The importance of ideas regarding rivers among peoples of the east coast was in fact long ago noted by Ralph Linton, who pointed out that peoples of the region often have "a sacred river into which the umbilical cords of children are thrown" (Linton 1928:372). Only if this has been done, he said, can a person be 
buried in the group's tombs, structures which are themselves usually built near the sacred river. Linton also noted that when a people moved into a new locality they baptized and named the river there with water drawn from the sacred river from where they had come (1928:373). Whilst drawing on a limited range of data, Linton's remarks are highly suggestive in the light of subsequent ethnographic research.

More recently, in an analysis of the importance of water in Tañala political symbolism, Philippe Beaujard (1983a:313-314) has pointed to the contrasting importance accorded to deep pools and whirlpools in the central highlands (of which the lakes of Vazimba queens are one example), and river mouths and confluents on the east coast (see also Hurvitz 1986). Whilst one may feel sceptical regarding Beaujard's ideas about religious heritages and syncretism, one point he makes is worth following up:

It appears ... that the apparent retracing of water to its source in the whirlpool of a confluent or deep river pools may be the basis of a religious attachment of rulers to these places (1983a:314).

Unfortunately Beaujard does not develop this interesting idea, neither in terms of ideas regarding sources and origins, nor of what is involved in attachment to places. However, an analysis of the significance of water in Temanambondro ritual reveals not only the fundamental importance of rivers, but also that these water courses are conceptualized as a "source" or "origin", and that they are an important part of what attaches people to place. Furthermore, the points noted by Linton about umbilical cords, tombs and the "baptism" of new localities, are related to ideas about "sources", "origins" and connectedness to place, for each participates in a play of images involving the organizing metaphor of "roots". And it is to rivers, "roots" and the Temanambondro that I now turn.

\section{Temanambondro: A Riverain People}

Those people who refer to themselves as Temanambondro currently occupy the lower reaches of the Manambondro, Isandra and Iavibola Rivers, which lie a little to the south of the Tropic of Capricorn in southeast Madagascar. My own fieldwork was principally carried out in the lower Manambondro Valley, which during the early 1990s was home to around 8,000 subsistence agriculturalists. Although many people produced small quantities of cash-crops, principally coffee and cloves, the vast majority of people's livelihood centred on the growing of wet rice, cassava and sweet potato for household consumption.

The significance of the name Temanambondro will become clear below, but it does not figure among the eighteen so-called "ethnic groups" or "tribes" of Madagascar, and here the Temanambondro disappear under the appellation Tesaka (or Antaisaka in the official dialect of Malagasy). In fact, a previous ethnographer of the latter people has referred to the Temanambondro as one of 
a small number of "assimilated tribes" of the Tesaka (Deschamps 1936:79). But, although they are socially and culturally speaking very similar to these northern neighbours (as indeed they are to virtually all the peoples of southeast Madagascar), Temanambondro claim different historical and geographical origins to the Tesaka, and do not think of themselves as "assimilated" at all.

Temanambondro are a ritual polity comprising a number of named "kinds" or Ancestries (karazana), each of which has its own tomb (kibory); Ancestries are in turn divided into one or more "house-groups" (trañobe, lit. "big" or "great houses"). Ancestry identity, and thus house-group membership, is traced through the "father", although I prefer not to call either grouping "patrilineal" as I feel this tells us little of any consequence. Although neither Ancestries nor house-groups are corporate in the full sense of the term, both groups are at their most cohesive in the context of ritual, especially funerals. Furthermore, whilst Ancestries are not localized groups, by and large house-groups comprise a distinct group of houses arranged around a small plaza which is the group's ritual and often physical centre. Finally, Ancestries and house-groups are neither "exogamous" nor "endogamous", nor is either grouping linked to others by a system of "alliance". In fact, these groups are not the basis by which marriages are made, although Temanambondro have a preference for marrying people to whom they are in some way related. ${ }^{2}$

Temanambondro villages may contain one or more house-groups, and one or more Ancestries. The one with which I am most familiar is Manambondro village, by far the largest in the region, and home during the fieldwork period to around 3,000 people, divided into some fifty-eight house-groups of eleven named Ancestries. The name of the village, however, has an interesting history, for the very word Manambondro is to some extent an important "container" (Casey 1987:186) of Temanambondro collective memory. The importance of the relationship between place and memory has occasionally been remarked on (for example, Relph 1985; Casey 1987), and nowhere is this more apparent than in the narrative that recounts the origins of the Temanambondro, a story which reveals people's connectedness to place through a body of water, the river that flows, and the source of the water of blessing.

This story tells how the earliest arrivals of the Temanambondro journeyed from the region of Ikongo in the eastern rainforests of Madagascar, some 200 $\mathrm{km}$ north of their present home, a region they appear to have left more than 350 years ago. In the region of Ikongo lived a man named Andriamaroary, whose village was located alongside a river named Manambondro. In the wake of a large storm a group of people led by Andriamaroary left their home village, and with them they carried a gourd containing some "ancestral water" (ranon-drazana) from the Manambondro River. The group journeyed south, stopping at various points on the way, until they finally came to the mouth of a large river. There, 
a sign satisfied a "diviner" (ombiasy) among the group that here was the place to settle, and Andriamaroary agreed. However, soon after another sign appeared, this time of habitation upriver, and so Andriamaroary and his followers set off to investigate. Not far away they found an island in the middle of the river and on it a half-deserted village, occupied by among others a people known as Ramañera. Fighting ensued and the newcomers triumphed. Andriamaroary decided that he and his followers too would live on this island, which still lies in a river whose old name no one remembers, for after making his decision Andriamaroary took the gourd that had been carried from the north, and emptying the contents into the water flowing past his feet, he named the river after the one they had left behind them, Manambondro. ${ }^{3}$

So the name has remained, memorial testament to the ancestral origins of the arrivals from the north, although the inhabitants of the island were moved to the mainland around 1905, not long after the imposition of French colonial rule. The village that was created as a result of this forced relocation is also named Manambondro, after the river that flows past it, but as one elder insisted, "it is not the village but the river that is called Manambondro" (tsy ty tana ty fa ñe renirano atao hoe Manambondro). The people who live here then, and in other villages within the domain of the polity that was established here, are Temanambondro, literally "people of the Manambondro River".

The very act of naming the river reveals how central this water course was in the constitution of the ritual polity established by Andriamaroary and later extended by his successors. On the journey from the north Andriamaroary had been accompanied by his daughter, as well as by her three sons, between whom he divided the polity he had founded. From the daughter's three sons stem the former "ruling" (andriana) Ancestries of the Temanambondro polity, each of which ruled a separate domain. The daughter's eldest son established himself and the Andratsimaniry Ancestry on the lower Isandra and Iavibola Rivers, while the second eldest founded the polity ruled by the Andriatsiazomosary in the middle Manambondro Valley. These two domains were to some extent autonomous ritual polities, but continued to recognize the superior status of the polity ruled by their youngest brother and the Andonakavaratra, centred on the island of Antokonosy on which Andriamaroary had chosen to settle.

Those ruled by these "ruling" Ancestries fell into two ranked groups of named Ancestries, some of which had accompanied Andriamaroary on his journey, whilst others arrived at later points in time. Of higher status were those Ancestries known as "children of rulers" (anak'andriana), while below them was a large group of subject Ancestries, including the Ramañera, the original inhabitants of the land.

The power and authority of the "ruling" Ancestries was principally constituted in terms of ritual agency, and through other forms of symbolic 
practice such as consumption and display. The hierarchical division of these polities, with "children of rulers" holding intermediate status between "ruling" and subject Ancestries, lasted until the last decade of the nineteenth century, when the subject peoples which rose up against the "ruling" Ancestries and their "children". In the aftermath of these events, many, although not all, of the practices that signalled the dependent status of subject Ancestries were appropriated by the former subject groups, who gained a great deal of politico-ritual autonomy. On the lower Manambondro, the subject groups which rose up combined under the name Zafimananga, a name they still use to identify themselves as a political entity. Zafimananga is opposed in people's minds to Andrafolo, the name used to refer to the Ancestries formerly holding the status of "rulers" and "children of rulers" who now live in Manambondro Village.

Despite the demise of the ritual polity in its old form, Temanambondro continue to recognize themselves as a distinct "kind" of people in part through their ritual practices, as well as through the place they live in. In fact, place and ritual are mutually constituted in many ways, for just as place can be constituted ritually, so too are rituals defined by the places in which they are performed. For Temanambondro this mutual constitution of place and ritual involves a further element, a constant feature of the environing landscape and a focal image in people's sense of place: the Manambondro River.

\section{Life, Death and the River}

Since the days of Andriamaroary the Manambondro River is said to have gradually grown in size. Whereas it was once possible to reach the island of Antokonosy from the mainland by crossing a bridge made from a felled tree, now it is only possible to do so by canoe. At its largest the river is some $200 \mathrm{~m}$ or so wide, and the flow of the water often so slow as to be virtually imperceptible. Most of the villages of the lower Manambondro Valley lie close to the river, and people's everyday lives are intimately entwined with this majestic and slow-moving body of water. People descend to its banks several times a day to draw water for cooking and drinking, to wash themselves and do their laundry, and to embark in their canoes for their rice-fields and other agricultural lands which either lie close to the river or to one of its tributaries.

Besides being a constant presence in people's everyday lives, as the story of Andriamaroary highlights, the river is also an important place in ritual terms, and an "elemental image" and "organizing metaphor" (Fernandez 1982) of the ritual imagination. The Manambondro is referred to as the "ancestral water" (ranon-draza) of the Temanambondro, and is an example of what Linton referred to as a "sacred river", although the term is somewhat misleading if understood in an absolute sense. In fact the sacrality of water is only evident in ritual contexts, whilst in other situations it is not (see also Smith 1987:103-106), and ritual contexts aside, people do not treat it with awe or reverence. However, the 
water that many people drink and wash in is also said to possess "sacred efficacy" (hasy), and features in a number of different rites. In marriage, for example, river water is used to make a paste that enables the spouses to "take away the taboo" (mangala fady) that exists between them. River water can also be drunk as a "cure" (hetry) when someone is challenged to a truth ordeal (tange), and during one ritual I witnessed that was aimed at "cleansing" (mampadio) a man of the "bad things" (raha ratsy) he had seen while serving in the Malagasy army, he was anointed with the blood of a sacrificed zebu, an act followed by a ritual bath in the river. The Temanambondro term for blessing also reflects the importance of water, for these acts are known as fafy rano, "sprinkling water". However, the most formal blessings performed during large rites involve the use of locally brewed sugar-cane alcohol, although in the past a mixture of honey and river water was said to have been used.

The water of the Manambondro River, however, is not simply a source of "sacred efficacy", for as the story of Andriamaroary indicates, it is also an important spatial image of Temanambondro self-definition, and thus an elemental image in people's sense of place. Indeed, the river frames people's lives and experience, not just on the everyday level, but also more dramatically in ritual terms, and in particular through its place in the rituals which accompany birth and death.

At birth the placenta (razana, also meaning "ancestor") of the newborn child, said to be the child's "elder sibling" (zoky), is taken and interred in the grounds of the house-group of the child's "father". A few days later, along with clippings from the first cutting of the child's hair and nails, the child's umbilical cord (foitra) is put in a small piece of cloth, which is then tied and weighted with a stone. Shortly before dawn on an auspicious day, the child's "father" takes the weighted bundle to the "throwing-away-place of the umbilical cord" (fañariana tadim-poitra), and there he throws it a long way out into the middle of the river after an invocation that places all Temanambondro in a spatio-temporal relationship to the river from which they take their name.

We announce to you ancestral water the throwing away of the umbilical cord of R. Whether having gone north, gone south or gone west then [if s/he] becomes attached to the land there only you water of the Manambondro will s/he not forget. ${ }^{4}$

No matter where they are born, the navel cord of each Temanambondro returns to be thrown into the river of its ancestors, and if this has not been done then it is said that the person will be denied burial in the tomb. ${ }^{5}$

What is especially significant here is that the rite which in part makes a person Temanambondro through defining personhood in relation to place, the river from which the Temanambondro take their name, and Temanambondro 
as a whole, are all referred to as "children" (taranaka) of the Manambondro River. Furthermore, the rite anticipates the person's death and burial, another ritual which is a defining feature of personhood, for the "throwing-away-place of the umbilical cord" is immediately alongside the "harbour-place of the corpse" (tsirañam-paty) from where the person will leave for interment in the tomb after death. In fact this place, and the river and its waters, are especially prominent in Temanambondro rites of burial and commemoration.

When a person dies, the body is returned to the "female house" (trañom-bavy) of the house-group, and there the corpse is prepared for burial. Before it can be dressed in clothes and enveloped in various shrouds, however, the corpse must be washed. Water for this is drawn from the river at the "harbour-place of the corpse", and it is here also that the dead are given their "final farewell" when they leave behind their living relatives in the village for burial in the tomb downstream. Rarely more than a day after death, the corpse is taken from the "female house" and carried on a bier down to the "harbour-place of the corpse". Once there the corpse and bier are placed in a large dugout canoe which, when it leaves the bank to the sound of the cries of the mourners, heads out into the mid-stream, the place where the person's umbilical cord had been thrown shortly after their birth. Then the canoe turns to head off silently downstream, gently paddled toward the tomb that lies near the mouth of the river.

After they have been buried (the period of time varying from one or two days to several years), the dead person is commemorated in a second rite (takombato), the culmination of which is the placing of commemorative objects in a memorial ground adjacent to the tomb, the point at which the dead achieve ancestorhood. Temanambondro commemorate their dead in the form of a carved wooden post to which the horns of sacrificed cattle are attached, and with a standing-stone often less than a metre in height. Prior to the rite itself the wood and stone needed are sought outside the village. Men wandering "in the forest" $(a \tilde{n}-a l a)$ or working "in the bush" (añ-ahitra) often make note of any rocks they see which are likely to serve well as standing-stones. Although these are nowadays usually left where they are found until they are needed for a commemoration, it was previously customary to take a stone to the river, one of its tributary streams, or to the "harbour-place of the corpse" and leave it there until required.

A similar practice is entailed in obtaining the wood for the carved post, or teza, a name which also refers to the class of hardwoods from which the post is made. Although sometimes fashioned from old hardwood house-posts, some teza are still made from living wood cut from the forest following the customary method of doing so. A group of men depart for the forest and spend two or more days away cutting trees that are then brought back to the village. Until the point arrives when they are to be fashioned into memorial posts, when the "head" of 
the teza has carved into it an image of the river-dwelling crocodile and a gourd, these cut trees are left in the river, tied to the river bank at the "harbour-place of the corpse".

Just as the disposal of the umbilical cord anticipates the place from which the person will one day leave for burial, the place where the stone and tree are kept also anticipate their own departure at the close of the commemorative rite. After the stone has been danced into the village and taken to the dead person's house-group, and after the cut tree has been fashioned into the memorial teza, they are both brought in an exuberant dancing procession to the "harbour-place of the corpse" and loaded onto canoes that take them down-river to be erected alongside the tomb in which the person they commemorate was buried. Their point of departure and the route taken as they travel reproduces that of the corpse they represent in so many ways. ${ }^{6}$

Temanambondro are people of the Manambondro River, and the rites that mark the beginning and end of life vividly demonstrate this fact, for these rites, which are crucially important in the constitution of personhood, are performed in relation to the river. To have had one's umbilical cord disposed of in the Manambondro River, and to be part of an Ancestry which has a tomb at the mouth of the Manambondro River in which one will be buried, is part of what it is to be Temanambondro. The river is important then, not just as a source of water possessing "sacred efficacy", but also as the place through which Temanambondro are constituted as full and moral persons, both in life and in death. In addition to its significance in the making of persons, the river is also of great importance in the creation of the Temanambondro as a polity, a collectivity of named Ancestries, for the polity is itself constituted through relations defined in terms of place, or more particularly, in relation to the river.

\section{The River and the Polity}

The story of Andriamaroary's journey highlights an important "origin" (fototra) of the Temanambondro polity, the place from which Andriamaroary and the gourd of water came. Yet it is also recognized that Ancestries that originate from among those who followed Andriamaroary are in a minority among the Temanambondro as a whole, and that those who arrived in the region after Andriamaroary came from different places, and therefore have different historical and geographical "origins". What unites the Temanambondro, however, is not their "origins", although like those of the Ancestries who accompanied Andriamaroary, most arrived from the north, but the place in which Temanambondro now live. "Everyone comes from somewhere different", remarked one man, "but the place brought them together" (samby mana ñe viany aby $\tilde{n}^{\prime}$ olo, fa ñe faritra nampitambatra anazy), and those places which are seen as especially significant in bringing people together are the Manambondro River and its embouchure, as well as the tombs which are located there. 
The idea of unity between people of different "origins" being created through the river was clearly articulated to me by a number of people. As two different men put it, the Manambondro River is the "great trunk" (fotora be), it is "the root which is the basis of what makes the Temanambondro Temanambondro" (ñe fototra iorenany maha-Temanambondro ñe Temanambondro). The river unites people under one name - Temanambondro - and defines them as "one kind of people" (karazan'olo raiky). The river mouth is also important as a place which unites Temanambondro: "there is a state of relatedness between people [who] share a river mouth" (pihavana ñe olombelona mana vava rano raiky), one man told me, "the embouchure makes people one" (miray olo ñe vinñay). In fact the lands occupied by Temanambondro are crossed by more than one river, but the Manambondro takes precedence among these, both because this is where Andriamaroary poured the gourd of water and because at its mouth lie the tombs and memorial grounds of most Temanambondro Ancestries.

Although Temanambondro are united through the river, its embouchure and their tombs, these "houses of the ancestors" (trañon-drazana) also signal divisions among them, divisions of Ancestry and hierarchy. Here the unity of the "great trunk" gives way to differentiation, idiomatically represented in terms of "branches": as one man put it, employing a common turn of phrase to stress both unity and difference in the same context, "we [Temanambondro] have only one root but everyone has their own branch" (fototra raiky avao ahay fa samby mana ñe sokazany). The use here of the image of "branches" can be understood in different ways. Firstly, it can be seen to refer to the fact that although all Temanambondro share one "root" (fototra) in the Manambondro River, various Ancestries have different historical and geographical "origins" (fototra), the places from which they migrated before coming to the Manambondro. Secondly, these "branches" refer to a more local articulation of difference, one that embodies difference in the architectonics of ritual spaces and places.

Although the rites performed at the "throwing-away-place of the umbilical cord" and the "harbour-place of the corpse" are part of what makes a person Temanambondro, thus creating unity and identity among people through their relation to the river, the exact place where the rites are performed also differentiates persons in terms of Ancestry. Each Ancestry has its own "throwing-away-place of the umbilical cord" and "harbour-place of the corpse", although in some cases these are shared with another Ancestry. Thus the rites of birth and death take place at different places along the river, according to the person's Ancestry identity.

This differentiation of Ancestries through ritual places is also to be found in the spatial positioning of tombs. Although each Ancestry has its own tomb at the river mouth, places which are themselves talked of as "roots" (fototra) of an Ancestry, their spatial arrangement is an embodiment of hierarchical relations 
within the polity, both past and present, highlighting divisions which Temanambondro talk of in terms of "branches" (sokazana).

The hierarchical division of the polity between Ancestries who were "rulers", "children of rulers" and subjects was concretized in the spatial location of tombs, as was the succession of Ancestries who arrived after the polity had been founded. Temanambondro hierarchy is most graphically realized in the spatial positioning of bodies and objects, ranging from where people sit in houses, through the lay-out of house-groups, to the positioning of tombs (see Thomas $1995,1996)$. In such contexts the spatial articulation of hierarchy is principally played out through the cardinal points: north and east are respectively "above" (ambony) and therefore superior to south and west, themselves "below" (ambany).

An aerial view of the mouth of the Manambondro River would reveal, in small open spaces cleared from the surrounding forest, a myriad of roofed structures arranged in clusters and oriented to the cardinal points. These are the tombs of Temanambondro Ancestries, located on both the north and south bank of the embouchure. The tombs of the Ancestries who accompanied Andriamaroary are to be found on both sides of the river, with the tombs of "rulers" and "children of rulers" found to the north, and the tombs of subject Ancestries to the south. The tombs of Ancestries who arrived later, known as "people who came after" (olo avy tafara) and including both "children of rulers" and subject groups, are all found to the south of the embouchure. The positioning of tombs therefore gives concrete spatial expression to relations of hierarchy and temporality. The highest ranked and first arrived Ancestries are found to the north of those of the same rank who arrived after, and the northernmost tomb on the north side of the river is that of the former "ruling" Ancestry on the lower Manambondro.

Relations of hierarchy are played out in the context of death in another way too. Although many of the forms of ritual agency, consumption and display which differentiated Andrafolo from subject Ancestries on the lower Manambondro River are no longer practised, Andrafolo and Zafimananga take different routes around Antokonosy, the island where Andriamaroary and his followers first settled, when taking corpses and memorial objects down-river to the tombs. In keeping with the spatial ordering of hierarchy, only Andrafolo may pass the island "at the great head" (an-dohabe), that is to the east, while Zafimananga must pass to the west, literally "at the door" (am-baranga). ${ }^{7}$

Whilst the river itself unites the Temanambondro, "making them one", places, objects and trajectories associated with umbilical cords, tombs, corpses and memorial objects also highlight divisions within the polity, differentiations articulated in relations to the river. Thus although the river is the "root" and "great trunk" of the Temanambondro, the "throwing-away" and 
"harbour-places", tombs and routes taken by canoes to the tombs graphically illustrate the idea that each "root" and "trunk" has its "branches".

\section{The "Roots" of Place}

While accepting that the inclusion of Madagascar in the Austronesian world is a classification fraught with complication, what is perhaps most striking about Temanambondro ideas pertaining to the river in the context of comparison within this region is the frequent use of images of "origins", "roots" and "trunks", and their proliferation and differentiation as "branches". As Fox (1993:16-23) has recently noted, throughout much of the Austronesian-speaking world, and particularly in Southeast Asia, there is a concern with "origins" of various sorts which "constitutes a fundamental epistemological orientation and takes on a remarkable variety of forms" (1993:16-17). This concern manifests itself in such things as the complex and sometimes poetic narratives of geographical and historical origins of peoples and their movement across the landscape, and in the wide range of botanical metaphors, such as "roots" and "trunks", and their outgrowth in the form of "tips", "leaves", "flowers" and so forth, which are used to represent a variety of social, spatial and temporal relations. Furthermore, many of the words used to express these ideas in Austronesian languages are cognate terms containing the syllable $f u$ or $p u$ (Fox 1980:14; Errington 1989:205 passim).

Temanambondro idioms and images appear to be related to this widespread Austronesian phenomenon, both at the metaphorical and linguistic level. A wide range of botanical metaphors are employed in the context of marriage, where human fertility is likened to the growth and reproduction of plants, as well as in idioms of relatedness, where, for example, the person is said to have "eight sides" or "branches", of which that of the "father" is referred to as the most important "root", the teña fototra (Thomas 1996). More significant in the present context, the river itself is imagined through a multitude of images involving "roots" and "trunks". The Manambondro River to the north is spoken of as the "origin" (fototra) from which Andriamaroary came, while the river into which Andriamaroary poured the gourd of water and named Manambondro is said to be the "great trunk" (fotora be) and the "root which is the basis of ... the Temanambondro" (ñe fototra iorenany maha-Temanambondro ñe Temanambondro). At the mouth of this river lie the tombs, themselves the "roots" (fototra) of the various Ancestries, while into the river is thrown the "root of life" (fototra ñe fieñana), the child's umbilical cord (foitra). ${ }^{8}$

These terms, which would seem to represent a Temanambondro variant of the concern with "origins", comprise an important set of idioms and images through which Temanambondro imagine "being-in-place" (Casey 1993) as a state similar to the rootedness of plants. Temanambondro are multiply rooted in place: through bodies, buildings, and the environing landscape; through placentae 
and umbilical cords, houses and tombs, and through the slowly flowing Manambondro River. Furthermore, this multiple-rootedness is what makes being-in-place a being-in-the-world-through-relations-with-others, with parents, with those of a person's Ancestry, and with other Temanambondro. Aspects of personhood, and personal and collective identities are therefore constituted through various "roots", themselves in turn rooted in places.

It appears therefore that an important aspect of Temanambondro ritual practice is the process of creating place, and of placing people in place, both processes involving the creation and placing of "roots". This at least would appear to lie behind the naming of the river, the disposal of the umbilical cord, and the burial and commemoration of the dead. The first rite involves the creation of a "root", while the latter two relate people to this "root" through the corporeal "roots" of their own bodies, and through tombs, the "roots" of Ancestries.

It would be a mistake, however, to assume that being-in-place through "roots" implies stasis, permanence or absolute fixity. For while "roots" may be part of the way people imagine connectedness to place, like many of the plants Temanambondro cultivate and to which they liken many aspects of social relations, they can be "cut" and transplanted to new places. In fact, a place with "roots" may be the starting point of migration to other places, just as it may be a place into which people have migrated and settled, and both places are referred to as fototra, both "origin" and "root".

From Beaujard's (1983b:35-49) account of Tañala migration stories it would seem that Andriamaroary's own ancestors were immigrants to the region in the north named Manambondro. In the shape of Andriamaroary and his followers these people moved on again, migrating south until they settled on the island of Antokonosy and named the river in which it stood after that from which they had come. More recently still, this migratory process has occurred once more. In the wake of a violent encounter in 1904 between colonial forces and Temanambondro insurgents that marked the end of an uprising against French colonial rule, a number of people from villages on the lower Manambondro and Isandra Rivers left their lands and fled south, finally settling some $150 \mathrm{~km}$ away, a little to the west of the town of Fort Dauphin. Now fully "attached to place" (tama) and rooted in their new lands, up until the mid-1960s these émigrés returned the bones of their dead for final interment in the tombs at the mouth of the Manambondro River, the "origin" place from which they had migrated. This they no longer do, having permanent tombs and memorial sites in the lands they have settled. In founding these places of burial and commemoration they had to perform the rite of "cutting the root" (fira fototra), for only then could they independently establish themselves in the place they had moved to. In "cutting the roots" that connected them to one place, they were able to transplant them to another. 
Thus the creation and cutting of "roots" is part of a spatio-temporal process. A people establish themselves in a place and put down "roots", naming the river there, and inscribing themselves on the landscape through working, building on and burying in the land. At some later date they move on and establish new "roots" in new places, "cutting" the roots that connect them to the old. But as with the roots of the cultigens they transplant, the "roots" people make in places take time to establish themselves and flourish. Some time after settling on the island in the middle of the river he renamed Manambondro, Andriamaroary returned to the north, to the river whose water he had drawn in a gourd, and there he is said to have been buried. And on the death of his daughter she too returned to the "origin" and "root" of her father's "ancestral water" for burial. Not until the deaths of her sons did Temanambondro begin to bury their dead at the mouth of the Manambondro River. Only then had they become rooted in place; only then were they truly zana tany, "children of the land".

Images of "roots" are not only one of the ways in which Temanambondro imagine connectedness to the place they dwell in, for "roots" also embody other important ideas, such as the growth and proliferation of people rooted in places, and the ability of people to move by "cutting" the "roots" that connect them to one place and transplanting them to another. For Temanambondro, being rooted in place is therefore a dynamic and regenerative process, and in images of "roots" we find a poetic elaboration through the trope of metaphor on some fundamentally important aspects of their experience of being-in-the-world.

\section{References}

Astuti, Rita

1993 Food for pregnancy: procreation, marriage and images of gender among the Vezo of western Madagascar. Social Anthropology 1:277-290.

Beaujard, Philippe

1983a Les conceptions symboliques de la royauté et l'exercise du pouvoir dans les royaumes Tanala de l'Ikongo (XVIIIe-XIXe siècles). In F. RaisonJourde (ed.) Les souverains de Madagascar, pp.299-336. Paris: Karthala.

1983b Princes et paysans: les Tanala de l'Ikongo. Paris: L'Harmattan.

Bloch, Maurice

1986 From blessing to violence: history and ideology in the circumcision ritual of the Merina of Madagascar. Cambridge: Cambridge University Press.

1987 The ritual of the royal bath in Madagascar: the dissolution of death, birth and fertility into authority. In D. Cannadine and S. Price (eds) Rituals of royalty, pp.271-297. Cambridge: Cambridge University Press.

Casey, Edward S. 
1987 Remembering: a phenomenological study. Bloomington: Indiana University Press.

1993 Getting back into place: toward a renewed understanding of the place-world. Bloomington: Indiana University Press.

Chandon-Moet, B.

1972 Vohimasina, village Malgache: tradition et changement dans une société paysanne. Paris: Nouvelles Editions Latines.

Cotte, Paul Vincent

1947 Regardons vivre une tribu Malgache: les Betsimisaraka. Paris: La Nouvelle Edition.

Deschamps, Hubert

1936 Les Antaisaka: géographie humaine, coutumes et histoire d'une population Malgache. Antananarivo: Imprimerie Moderne de l'Emyrne.

Deschamps, Hubert and Suzanne Vianès

1959 Les Malgaches du Sud-Est. Paris: Presses Universitaires de France.

Elle, Bjorn

1905-6 Note sur les tribus de la province de Farafangana. Bulletin de l'Académie Malgache 4:116-123.

Errington, Shelly

1989 Meaning and power in a Southeast Asian realm. Princeton, NJ: Princeton University Press.

Feeley-Harnik, Gillian

1991a Finding memories in Madagascar. In S. Küchler and W. Melion (eds) Images of memory, pp.121-140. Washington, DC: Smithsonian Institution Press.

$1991 \mathrm{~b}$ A green estate: restoring independence in Madagascar. Washington, DC: Smithsonian Institution Press.

Fernandez, James W.

1982 Bwiti: an ethnography of the religious imagination in Africa. Princeton, NJ: Princeton University Press.

Fox, James J.

1980 Introduction. In J.J. Fox (ed.) The flow of life, pp.1-18. Cambridge, MA: Harvard University Press. 
1993 Comparative perspectives on Austronesian houses. In J.J. Fox (ed.) Inside Austronesian houses, pp.1-28. Canberra: Department of Anthropology, Research School of Pacific Studies, The Australian National University.

Huntington, Richard

1986 The transformation of the Bara rural economy. In C. Kottak et al. (eds) Madagascar: society and history, pp.299-319. Durham, NC: Carolina Academic Press.

Hurvitz, David J.

1986 The "Anjoaty" and embouchures in Madagascar. In C. Kottak et al. (eds) Madagascar: society and history, pp.107-120. Durham, NC: Carolina Academic Press.

Kus, Susan and Victor Raharijaona

1990 Domestic space and the tenacity of tradition among some Betsileo of Madagascar. In S. Kent (ed.) Domestic architecture and the use of space, pp.21-33. Cambridge: Cambridge University Press.

Linton, Ralph

1928 Culture areas in Madagascar. American Anthropologist 30:363-390.

1933 The Tanala, a hill tribe of Madagascar. Chicago: Field Museum of Natural History.

Middleton, Karen

1995 Tombs, umbilical cords and the syllable fo. In S. Evers and M. Spindler (eds) Cultures of Madagascar: ebb and flow of influences. Leiden: International Institute for Asian Studies, Working Paper Series 2.

Molet, Louis

1956 Le bain royal àMadagascar. Antananarivo: L'Imprimerie Luthérienne.

Nérine Botokeky, Eléonore

1983 Le fitampoha en royaume de Menabe: bains des reliques royales. In F. Raison-Jourde (ed.) Les souverains de Madagascar, pp.211-220. Paris: Karthala.

Rahatoka, Salomon

1984 Pensée religieuse et rituels betsimisaraka. In J-P. Domenichini et al. (eds) Ny razana tsy mba maty: cultures traditionelles Malgaches, pp.31-92. Antananarivo: Editions de la Librairie de Madagascar.

Rajohnson, Henri

1908 Etude sur les Antanosy et les Antandroy. Bulletin de l'Académie Malgache 6:177-196. 


\section{Relph, Edward}

1985 Geographical experiences and being-in-the-world: the phenomenological origins of geography. In D. Seamon and R. Mugerauer (eds) Dwelling, place and environment, pp.15-31. Dordrecht: Nijhoff.

\section{Rolland, Dominique}

1984 Les Antemoro de la Matitanana. In J-P. Domenichini et al. (eds) Ny razana tsy mba maty: cultures traditionelles Malgaches, pp.93-126. Antananarivo: Editions de la Librairie de Madagascar.

\section{Smith, Jonathan Z.}

1987 To take place: toward theory in ritual. Chicago: University of Chicago Press.

Thomas, Philip

1995 Of houses, hearths and granaries: some aspects of gender among the Temanambondro of southeast Madagascar. Indonesia Circle 67 (special issue):340-358.

1996 Place, person and ancestry among the Temanambondro of southeast Madagascar. PhD thesis, University of London.

n.d.a. Burying and remembering: Temanambondro rites for the dead. Unpublished MS.

\section{Notes}

1 Fieldwork in the Manambondro region of southeast Madagascar was conducted between December 1991 and October 1993. The research was funded by the Economic and Social Research Council (UK), and carried out under the auspices of the Musée d'Art et d'Archéologie/Institut de Civilisations of the University of Madagascar in collaboration with the Ministère des Affaires Etrangères and the Ministère de l'Enseignement Supérieur of the Republic of Madagascar. My thanks to all these institutions for enabling me to carry out my work. A previous version of this paper was given at the London School of Economics in 1994, and I am grateful for the comments I received on that occasion, as well as to those people who, in various ways, have helped me shape the present form of the argument: Maurice Bloch, Cecilia Busby, Jennifer Cole, Gillian Feeley-Harnik, Jim Fox, Eric Hirsch and Roxana Waterson. Above all, however, my thanks go to my Temanambondro hosts, and in particular to those people who helped me find what I was looking for, and whose words are scattered throughout this paper: Kadia, Rabery, Tony and Mandiñ, as well as Nary and Nenety. Needless to say, I take responsibility for what lack of vision the paper currently displays.

2 I have chosen to refer to the named "kinds" (karazana) into which Temanambondro divide themselves as Ancestries with a capital so as to distinguish the term from its more general usage. For a more detailed discussion of Ancestries, house-groups, marriage and relatedness, see Thomas (1996).

3 This is an abbreviated version of the story of Andriamaroary but would be recognizable to those Temanambondro who know it in its more expanded form as a rendition of the main points. For other versions of the story, see Deschamps (1936:160-161) and Elle (1905-6:121-122); Elle, however, mistakenly attributes it to the Tevato, neighbours of the Temanambondro. For similar stories from the region involving what Linton referred to as the "baptism" of rivers, see Elle (1905-6:117, 121), Huntington (1986:301) and Beaujard (1983b:46-47, 76).

4 Mitadidy aminao ranon-draza ty. Hañary ñe foitrin'i $R$. Ndre niañavaratra. Ndre niañatsimo. Ndre niañkandrefana. Ndre de hotaman-tany añy de anao Rano e Manambondro ty avao tsy hohadiñony. 
5 The careful disposing (itself an act of placing) of placentae and umbilical cords is widespread throughout Madagascar, as is the idea that placentae are "siblings" of the newborn child: for the southeast, see Linton (1933:283-285), Deschamps (1936:134), Deschamps and Vianès (1959:56, 59, 88), Chandon-Moet (1972:102) and Beaujard (1983b:499). Whilst similar ideas and practices are widespread throughout Southeast Asia, given disputes over the Austronesian-ness of the Malagasy, it is noteworthy that they can also be found in parts of Africa: see, for example, Fernandez $(1982: 86,447)$ on the Bantu-speaking Fang.

6 The parallels between the corpse on the one hand and the standing-stone and teza on the other are several but cannot be gone into here. Neither can the significance of the images carved on the teza, one of a river-dwelling animal, the crocodile; and the second, a vessel for carrying water, the gourd. To some extent this outline of funerary rites refers to what Temanambondro see as a more traditional form of ritual practice. During fieldwork not all funerals strictly followed this pattern: for example, some commemorative monuments are now placed closer to the village, and standing-stones are occasionally made of concrete. A more comprehensive discussion of Temanambondro funerals is currently in progress (Thomas n.d.a.).

7 These terms of spatial reference are derived from the domestic space of houses: see Thomas (1995)

8 Note that in Malagasy the phoneme /u/ is written as an "o"; thus fo is pronounced "foo", as in "fool". In Malagasy the word fo means "heart", and comparative ethnography reveals a number of terms containing the syllable fo which display a recognizable thematic unity. Among Hazohandatse, children's umbilical cords (foetse) are taken and buried in a place which is referred to as the "root of our ancestors", fotorañ 'razan'ay (Middleton 1995); Vezo men are said to be the "source" or "origin" of pregnancy, fotoran'ateraha (Astuti 1993:281); Bemihisatra royal ancestors are referred to as the "fertile roots or genitals" (fototra) of the tree-person that is the royal tomb and which grows around them (Feeley-Harnik 1991a:136); and Betsileo use fototra to refer to the "foundations" of tombs and houses (Kus and Raharijaona 1990:29). In the Temanambondro dialect, fototra can be used to refer to the "origin" of something in time and/or space, such as the starting point of a journey, or the subject of a conversation; it is also used to mean the etymological root of a word (foto'teny). However, unlike fotora (which is used to refer to the trunks of trees), fototra is not used to refer to the roots of plants; here the word is vahatra. 